\title{
The Efforts of Improving the Professionalism of Lecturers towards the Presentation and Change of KKNI within the University Environment in Aceh
}

\author{
Khalsiah, Nur Asma and Marina \\ Universitas Malikussaleh Lhokseumawe, Aceh, Indonesia
}

\begin{abstract}
Purpose - The aim is to discuss the curriculum of KKNI, it's said to be still repressive for some educational stakeholders. It is not new about curriculum changes that are often shown to be a troublesome and complicated teaching system, especially for teachers who lack training in curriculum and inadequate facilitation.

Design/Methodology/Approach - Research data case study is argumentative research. The elaboration of the case is evidenced by literature review and related articles.

Findings - The research results show that research limitations/implications, however, doesnot accessed as a big problem because it only needs an effective approach for teachers (lecturers) who have not fully utilized the method of KKNI. In this paper, the author discusses the positive impact of KKNI on lecturers' performance aimed at generating Magnum Opus for universities of Aceh region. The level of influence is very high for the next 5 (five) years in the world of college. A variety of effects, among others; the steady standard of operational learning, improving the quality of education oriented to the publication of scientific journals and in the accumulated in prestigious academic journals and improve the quality of research.
\end{abstract}

Originality/Value - The associated with the presence of the new curriculum at universities, especially universities in Aceh is very significant

Keywords The Effort, Improving of Professionalism Lecturer, KKNI

All papers within this proceedings volume have been peer reviewed by the scientific committee of the Malikussaleh International Conference on Multidisciplinary Studies (MICoMS 2017).

\section{Introduction}

An education has a very central role and its function in building a region or country into an advanced and cultured region. Without education, an impossible progress will be embraced. With education, science becomes developed and able to create a high creativity that encourages progress in social, economic, and cultural fields. Even in Islam it clearly affirms

(C) Khalsiah, Nur Asma, Marina. Published in the Emerald Reach Proceedings Series. Published by Emerald Publishing Limited. This article is published under the Creative Commons Attribution (CC BY 4.0) licence. Anyone may reproduce, distribute, translate and create derivative works of this article (for both commercial and non-commercial purposes), subject to full attribution to the original publication and authors. The full terms of this licence may be seen at http://creativecommons.org/ licences/by/4.0/legalcode 
Proceedings of MICoMS 2017 that education is very important to humanity and its degree is elevated (The Holy Quran: AlMujadalah, verse 11).

The perfect integration of systems for educational creativity as stated by Katarina Tomasevski (2003) the education system to be part of its integral structure and its broad social and spatial processes. More precisely, there are political promises aimed at universal primary education every decade since the 1940s. That is, before the global era grew rapidly, education has been exploring the progress line to this day. Gunawan Sudarmanto (2011) added a great educational construction and strongly requires a conscious and planned effort to realize the learning process and integrity of curriculum blend in order to actively learners able to develop their potential. This means the complete design of college curriculum, the readiness of teachers and their roles in the classroom learning as well as full support (morally and materially) related institutions. Associated to all that, the principles set out in the Constitution are in accordance with Article 31 of the 1945 Constitution, paragraph 2, which states that every citizen shall have the right to receive and attend basic education and the government shall finance it. It is the responsibility of the government or the state in promoting its people. Then paragraph 5 in more detail states the government advancing science and technology by supporting high religious values and national unity for the advancement of civilization and the welfare of mankind.

The flow of education is not as smooth as imagined. Many obstacles overtake from complex educational processes, changing curricula, difficult-to-adapt stakeholders, complex learners with a variety of characters and demands to be able to produce quality graduates. This paradigm is not an excuse to delay the educational procession but becomes the starting point for seeing the next stream to the stage of change. How is the role of government in realizing educational programs that have educated the nation's children? What kind of curriculum development is suitable to be implemented as the changes are suddenly impressed? How the reaction of educators among universities alongside KKNI? To what extent can the decision of Education Ministry in Permen ristekdikti able to dignified campus stakeholders in order to get a better education? All of the questions above because of the demands were not just produce prestigious graduates but the contribution of science can also be absorbed in the field work.

Supporting from various parties to smooth the process of university environment education trigger the birth of curriculum based on the principle of national education as outlined in the education law. Therefore the curriculum is not only discussed at the elementary to high school level but includes the university level as the delivery of generating productivity in the life of the community. As such, this study is not only a critique but also a suggestion for a university institution because of global demands and change. The persuasive indications are also presented in the presentation of this paper to get closer to KKNI. All university educators must be more pro-active in the governance of curriculum development as well as better prepared to face global challenges towards research-based universities. In relation to the above discussion, the authors want to put forward some things about the stigma of university environment education in Aceh associated with the new regulations that is the presence of KKNI and readiness of teachers in applying the curriculum in question. The authors conducted the research in the Universities of Aceh environment. So, the study was guided by the following research question: 1) How to improve lecturers at the university to face KKNI? 2) What is the role and function of KKNI towards learning at the university level? Research methods, results and discussion, and conclusions and recommendations will be presented following a literature review of relevant theory. 


\section{Literature review}

This section will provide a brief overview of the effort in the category to develop lecturers' potential for curriculum change and qualification requirements for national and international research universities. Conferring to Rehani (2015), the lecturer is an actively involved person in his professional development as an effort to improve the quality of the campus/institution where he teaches. The academic degree must be formal, have the competence of teaching, there is a certification of professionalism that is physical well-being and gain ability to fulfill the desire of national education.

The promoter by institutional stakeholders is also influential in improvising the professionalism of a lecturer. The other workshop performances as a first step to recognize self-development and institutions that lead to the quality of teaching and learning environment campus. This has a significant impact on campus ratings. Serambi Indonesia (Dec 07, 2017) LP3M Unsyiah reported that the campus rating is ranked 11th compared to 2016. This result is obtained based on Web metric data scheming is a system to measure the progress of a college through the university website. It can be understood that training or seminars on the progress of the institution closely related to the professionalism of a lecturer. This means to create a research-based university, the role of lecturers is very important. Currently, it has published scientific articles as much as 6,956, 291 books, and 26 patents obtained by scientists. A significant number was taken over the years.

Observe the professional development of lecturers (Redjeki, 2015) can be interpreted to maximize efforts to improve the competence, quality of learning, the role of academic teachers in universities. The image of a professional lecturer looks good in the community if it can show attitude to the community that he deserves the example of the surrounding community. The description is strengthened (Soetjipto and Raflis Kosasi, 2011; Redjeki, 2015), among others; legislation, professional organizations, peers, learners, workplaces, leaders, and jobs. Another theory explains the curriculum relationship and potential lecturer developers are interrelated with each other. In detail, Al Mawardi (2011) adds lecturers must have three competencies, namely; designing learning (teaching plan and materials); classroom procedures; and interpersonal skills. These three aspects are described in the college curriculum procedure. As regulated in Permenristekdikti No.44 of 2015 Article 1 defined by Ministry Of Higher Education (2015), KKNI is a set of plans and arrangements regarding graduate learning achievements, study materials, processes, and assessments used as guidelines for the implementation of study programs. KKNI is standing for Indonesia National Qualification Framework.

\section{Research methodology}

Descriptive and argumentative qualitative designs were implemented in this study. The design of the study is to describe the problems faced by lecturers towards changes in college curriculum KKNI and efforts taken to improve their performance. A single-mindedness of the problem to the professionalism of lecturers, curriculum changes, and the presence of KKNI. Young (1994) identified and described some prominent macrostructures of a university lecturer. Data were analyzed through literature review as data acquisition approach.

\section{Research finding and discussion}

\subsection{The effort and improving}

Quoting (Fabrice Henard \& Deborah Roseveare, 2012) as a proactive step, many institutions have implemented specific teaching and learning strategies and have devised mechanisms and instruments to improve the quality of education. With reduced resources and increased 
competition, these challenges may seem insurmountable, but higher education institutions can, and, help a lot to encourage quality teaching and improve student learning outcomes. The new paradigm of teaching and learning in the field of higher education actually implies: new connections on access to teachers, and wider range of communication and collaboration through learning platforms, re-designing the curriculum, bridging teaching and more intensive research, rethinking student workload and burden, improvements in pedagogy, use of technology, assessment models in line with student-centered learning, creating innovative learning platforms, providing guidance and guidance to students in new ways and methods, assessing impacts and documenting the effectiveness of teaching delivered.

Related to the effort and improvisation of lecturers towards the provision of quality education and high standard, According to Hussain( 2005) to produce high-quality human resources, we need high-quality education as well. In fact, in accordance with the demands of global challenges, we need to improve the quality of education from all dimensions so that the standard of education develops as global and international issues. To produce highquality human resources, we need high-quality education as well. In fact, in accordance with the demands of global challenges, we need to improve the quality of education from all dimensions so that the standard of education develops as global and international issues. The California Master Plan for Education (2003) describes the following components; 1) a qualified and inspirational teacher 2) a ready-made curriculum that can prepare all students for success in post-secondary education, work, and society.3) Textbooks, technology, and teaching materials should be aligned or linear. 4) Service/facilities supporting the adequate learning. 5) Qualified school or college administrators, to nurture an inviting and secure educational culture, and high appreciation of student achievement and teaching excellence. 6) A safe physical learning environment, complete infrastructure advice and wellmaintained. All of the above components must be provided to every student enrolled in public education, from preschool to university levels.

The peak of the problem is miscalculation or the calculation of campus financial management that has a negative effect on lecturers teaching on both campuses. The authors connectif management is not ready for implementation, then any institution will lead badly. The lecturers and the scientists they invite to join are losers and have no positive effect. The lecturers are less prosperous with honorable salary, to continue the learning process is hampered, the learning situation is not normal even decreased drastically. Are they not qualified? Of course, they are qualified and Highly paid but it was all in vain. The ideal to boost education to advance even the opposite. The role of stakeholders not only seeks the academic potential but also the internal and external potential of the campus that is affiliated to the vision and mission, plus the change and development of new curriculum learning methods. We want all campuses with the capacity and dignity including in Aceh.

\subsection{The professionalism of lecturers}

Ozga (1995) believed that the professionalism of a teacher becomes the basic rule for teachers or teachers in the shift of teacher-state relations. The lack of qualified teachers, community needs, and increased educational opportunities and organized labor force put teachers in a strategic market share and allowed teachers to retain their previously acquired license autonomy (Dale, 1989). In 1950-1960s many factors were combined to strengthen teachers' autonomy claims and to force states to maintain the rhetoric about rules, partnerships, and professionalism indirectly. Nowadays, the way taken is more elegant and different. All of its aim is to achieve the innovation of a so-called professional.

According to the author's analysis based on case data that appear in the field that there are still teachers or lecturers who have not met the criteria of the measured lecturer. Some 
private universities have not led to the professional competence in question. As an example; many fictitious practices, remote class opening, compacted lecture schedules, signature engineering evidence of attendance, and falsification of master numbers of dissertation students, as a major condition of graduation, indicated much plagiarism results. Tempo's search (2017) of the case has occurred at the State University of Jakarta (UNJ). The above phenomenon also does not close the possibility occurs in other areas or even in Aceh, although initially recorded learning programs that are agreed but can be deviated for some reason. Reinforced, the concerns of graduates whose diplomas are not recognized because the campus is not weighted and ultimately difficult to get a job (the author experience is rejected because of the graduate of one of the accredited local universities A). It's a fact; graduates have become unconfident with the results they have gained from years on their dreams. It needs a serious approach to handlethis great case. All must understand that the quality of the campus is strongly influenced by the work apparatuses in it. Based on the survey results of Kopertis Wilyah XIII-Aceh, there are 109 private universities in the province of Aceh included in the assessment of accreditation. Eight of them are already accredited; Aceh Polytechnic (accredited B), South Aceh Polytechnic, STIA Pelita Nusantara Nagan Raya, STIE Nationality Bireuen, Al Muslim University Bireuen, Gajah Putih University, Jabal Ghafur University Aceh Pidie and Muhammadiah University Aceh accredited C and each listed expired status (Dirjen Kelembagaan IPTEK \& DIKTI, 2016). Despite the fact that the accredited 'A' is Syiah Kuala University and UIN Ar-Raniry. The above facts show that many private college grounds are not yet in the good category even though they have produced many alumni. Then, it's closely related to the campus academic community including professional teachers and has qualified graduates. With the best regard to our teachers who have fought in such a way, but the point is to build a synergy between campus elements that take shelter to the best universities in the perceptiveness of society. Sofyan Efendi (2003) in his scientific seminar; Alluding to college governance to overcome the global era should pay attention to the overall order, campus management and able to target student interest. All of it involves the active role of government officials in order to bring positive stigma from the various lines. Hasan Tanang \& Baharin Abu (2014) suggested that to improve professionalism, teachers should be involved in activities including; education, teaching and learning process and professional development. Experts argued, professionalism emphasizes the mastery of knowledge management skills and strategies or implementation.

\subsection{Curriculum and KKNI}

Regarding the curriculum, Prof. Dr. S. Nasution, M.A (Kurikulum dan Pengajaran Tahun: 2008)The curriculum is a plan designed to smooth out the teaching and learning process under the guidance and responsibilities of schools or educational institutions and their staff (definitions taken from https://www.scribd.com/doc/53749423/Definitions-of-Curriculum). According to Oxford, Learners' Pocket Dictionary, the Curriculum is subjects included in a course of study or taught in school, college, etc. Now, the author wants to discuss the college curriculum or the so-called KKNI. The definition is already the author discussed in the literature review chapter. Here, the authors describe the condition of the college curriculum before the standard KKNI by Kemenristek dikti in 2013 ago and newly approved in 2015 means it has been two years running. So what is the composition of KKNI in achieving the target of academic passing for students and the balance for lecturers affiliated related? In this case, Syiah Kuala University has held several workshop or seminars on the curriculum.

Not only Syiah Kuala University qualified to facilitate lecturers, but other campuses also do the same. Example Muhammadiah University of Aceh (UNMUHA), the authors saved
The Efforts of Improving 
Proceedings of the soft copy of KKNI faculty Psychology of the university. The contents follow the KKNI MICoMS 2017 edition curriculum procedures that are oriented towards the vision and mission of the faculty, all tailored. But it does not change the content and main purpose of the curriculum. Clear written competence refers to the qualifying parameter 9 contained in the content. Learning Achievements at each level of KKNI are outlined in the description of attitudes and values, abilities, knowledge, responsibilities, and rights with concise statements called generic descriptors. Each descriptor indicates the depth and level of the learning achievement according to the study program level. Determination of Learning Achievement (CP) refers to standards that have been developed by DIKTI.

\section{Conclusion and recommendation}

The present study focused improving the professionalism of lecturers towards the presentation and change of KKNI within the university environment in Aceh, yet it more broadly explored the case. Discussing curriculum issues and targeting the achievement of teaching and learning by lecturers still needs to be straightened out and even followed up to invite to open the insight that the system is not a negative impact but vice versa. Local training and seminars for the improvement of teaching activities can be tailored to the needs of the campus, let alone see the global goal must be university-based research. Many other studies are similar to the author's idea although the segments are different; the case analysis is correlated with facts and literature studies. As a result, all elements must be actively involved in advancing their own local education to the level of national and even international level.

\section{References}

Al Mawardi (2011), "Peningkatan Kompetensi Pedagogik Dosen di Jurusan Teknik Sipil Politeknik Negeri Lhokseumawe". Jurnal BISSOTEK, Volume 6. No. 1

Danim. S (2013), "Pedagogi, Andragogi, dan Heutagogi”. Bandung, Alfabeta.

Dale. R (1989), “The State and Education Policy”. Milton Keynes, Open University.

Direktorat Jenderal Kelembagaan IPTEK \& DIKTI. (2016), "Kopertis Wilayah XIII- Aceh”. Retrieved in December 12, 2017, from http://kelembagaan.ristekdikti.go.id/index.php/kopertis-wilayah-xiiiaceh/

Effendi. S (2003), "Mengelola Perguruan Tinggi Dalam Menghadapi Tantangan Global”. Presented on national seminar of the chancellery chapter of Indonesia, at Makassar. Retrieved in December 4, 2017 from www.sofian.staff.ugm.ac.id

Haryati. S (2016), "Peningkatan Profesionalisme Dosen di Era MEA”. FKIP UNTIDAR. Magelang.

Hussain, J (2005), "Improving Teacher Quality, A Keyword for Improving Education Facing Global Challenge". TOJET Journal, Volume 4. Issues 1, article 4.

Henard, F \& Roseveare, D (2012). Fostering Quality Teaching In Higher Education: Policies and Practices. Organization for Economic Cooperation and Development (OECD)

http://kelembagaan.ristekdikti.go.id/index.php/2017/08/07/pemeringkatan-untuk-meningkatkan-mutuperguruan-tinggi/. (Accessed on December 4, 2017)

https:/elkimkor.com/2015/12/02/transformasi-perguruan-tinggi-dari-perguruantinggi-pengajaranmenuju-perguruan-tinggi-riset/.(Accessed on December 4, 2017)

$\mathrm{https} / / \mathrm{www} . g o o g l e . c o m /$ search?q=idealisme + dan + tantangan + sebuah + universitas\&ie=utf- $8 \& o e=$ utf-8. (Accessed on December 3, 2017)

https:/ejournal.ihdn.ac.id/index.php/JPM/article/download/99/106. (Accessed on December 4, 2017) 
http://unmul.ac.id/post/siapkah-perguruan-tinggi-menjalankan-kerangka-kualifikasi-nasionalindonesia-kkni-2016-1489417579.html. (Accessed on December 4, 2017)

Kemendikbud. Data Publication (2013). Retrieved in December 3, 2017from http://publikasi.data. kemdikbud.go.id/index.php?thn=all

Majalah Tempo. (September 24, 2017) Doktor Karbitan Kampus Guru. P. 52-53

Network. AJJN (2016). LP3M Unsyiah Gelar Pelatihan Dosen. Retrieved in December 3, 2017 from http://www.ajjn.net/news/

Ozga. J., (1995), "Deskilling a Profession: Professionalism, Deprofessionalisation and the New Mangeralism". in.

Rauhvargers. A (2013), "Global University Rankings and Their Impact Report II". Belgium: European University Association.

Redjeki. S (2015), "Pengembangan Profesionalisme Dosen dan Inovasi Pembelajaran”. Majalah Ilmiah Pawiyatan, Volume XXII. No. 3

Razaq. H (2012), "Pendidik Dalam Perspektif Alquran.Jurnal IAI Nurul Jadid”. Retrieved in December 4, 2017 from http://pps.iainuruljadid.ac.id/

Rehani (2015), "Students' perceptions on professional competece of lecturers at the Departement of Arabic education". Faculty of Islamic education and teacher training, state institute for islamic studies IB padang. Jurnal Pendidikan IB Padang. Volume 22, No. 1

Tanang, H \& Abu. B (2014), "Teacher Professionalism and Professional Development Practices in South Sulawesi, Indonesia". Journal of Curriculum and Teaching. Volume 3, No. 2

Tempo Media Group. (2017, 24 ${ }^{\text {th }}-30^{\text {th }}$ Editons). Liputan Khusus Kriminalitas. P. 52-61.

The Holy Al-Quran. Surah Al-Mujadalah, Verse.11

Young, L. (1994). University Lecturers Macro-structure and Micro Features. In Rido, A. (2010). Pattern of science Lecturer Discourse. Jurnal TEKNOTASTIK, Volume 8. No. 2

\section{Corresponding author}

Khalsiah can be contacted at ikal.ikal13@gmail.com 